\title{
Journal Reviewers in 2020
}

Recenzenci czasopisma w 2020 roku

Tatsiana Autukhovich (State University of Janki Kupała in Grodno, Belarus) Andrzej Baranow (Vytautas Magnus University, Lithuania)

Hassiba Benaldi (University of Algiers 2, Algeria)

Piotr Borek (Pedagogical University of Krakow, Poland)

Alexandr Brazgunow (Belarusian Academy of Sciences, Belarus)

Tadeusz Budrewicz (Pedagogical University of Krakow, Poland)

Mikałaj Chaustowicz (University of Warsaw, Poland)

Mintautas Čiurinskas (Vilnius University, Lithuania)

Zsolt Czigányi (Eötvös Loránd University, Hungary)

Heidi Dahlsveen (University of Oslo, Norway)

Hans Färnlöf (Stockholm University, Sweden)

Imène Fatmi (University of Algiers 2, Algeria)

Sabrina Fatmi (University of Algiers 2, Algeria)

Corinne Fournier Kiss (University of Bern, Switzerland)

Mariola Jarczyk (University of Silesia in Katowice, Poland)

Susana Maria Jimenez (University of Santiago de Compostela (USC), Spain)

Agnieszka Kaim (Institute of Slavic Studies, Polish Academy of Sciences, Poland)

Burcu Kayışcı Akkoyun (Boğaziçi University, Turkey)

Marek Kaźmierczak (Adam Mickiewicz University, Poland)

Jarosław Klejnocki (University of Warsaw, Poland)

Edyta Kociubińska (John Paul II Catholic University of Lublin, Poland)

Natallia Lameka (Belarusian State University, Belarus)

Marta Łukaszewicz (University of Warsaw, Poland)

Buata Malela (Mayotte University Center (Majotta), France)

Magdalena Malinowska (University of Silesia in Katowice, Poland)

Jadwiga Maszewska (University of Lodz, Poland)

Anzhela Melnikava (Belarusian State University, Belarus)

Yevhenii Vasylev (Rivne State University of Humanities, Ukraine)

Urszula Niewiadomska-Flis (John Paul II Catholic University of Lublin, Poland)

Joanna Orska (University of Wrocław, Poland)

Dawid Maria Osiński (University of Warsaw, Poland) 
Dariusz Pachocki (John Paul II Catholic University of Lublin, Poland) Jędrzej Pawlicki (Adam Mickiewicz University, Poland)

Snezana Petrova (University "Sts Cyril and Metodius", Macedonia)

Oleh Rarytskyi (Kamianets-Podilskyi Ivan Ohiienko National University, Ukraine)

Yaroslav Redkva (Chernivtsi National University, Ukraine)

Elżbieta Rokosz-Piejko (University of Rzeszow, Poland)

Marion Rutz (Justus Liebig University in Giessen, Germany)

Jörg Schulte (University of Cologne, Germany)

Gisele Vernhet Sigal (University of Pau and Pays de l'Adour (UPPA), France)

Ludmiła Sińkowa (Belarusian State University in Minsk, Belarus)

Beata Siwek (John Paul II Catholic University of Lublin, Poland)

Ryszard Siwek (Pedagogical University of Krakow, Poland)

Ludmiła Szypielewicz (University of Warsaw, Poland)

Joanna Teske (John Paul II Catholic University of Lublin, Poland)

Grzegorz Trościński (University of Rzeszow, Poland)

Theodora Tsimpouki (National and Kapodistrian University of Athens, Greece)

Kseniia Tverianovich (Russian Academy of Sciences, Russia)

Halina Tychko (Belarusian State University, Belarus)

Ewa Wierzbowska (University of Gdansk, Poland)

Marcin Wołk (Nicolaus Copernicus University, Poland)

Witold Wołowski (John Paul II Catholic University of Lublin, Poland)

Beata Zawadka (University of Szczecin, Poland)

Aleksandra Zywert (Adam Mickiewicz University, Poland) 